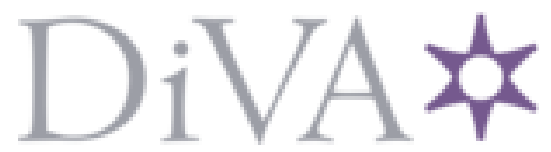

http://www.diva-portal.org

\title{
Postprint
}

This is the accepted version of a paper published in European Review of Economic History. This paper has been peer-reviewed but does not include the final publisher proof-corrections or journal pagination.

Citation for the original published paper (version of record):

Winton, P. (2012)

The political economy of Swedish absolutism, 1789-1809.

European Review of Economic History, 16(4): 430-448

http://dx.doi.org/10.1093/ereh/hes008

Access to the published version may require subscription.

N.B. When citing this work, cite the original published paper.

Permanent link to this version:

http://urn.kb.se/resolve?urn=urn:nbn:se:uu:diva-188431 


\section{The Political Economy of Swedish Absolutism, 1789-1809}

During the era of the Revolutionary and Napoleonic Wars (1792-1815) countries throughout Europe were affected by warfare on a scale previously unheard of. The military successes of Napoleon and the subsequent French ambitions to rewrite the map of Europe put new fiscal, military and political pressures on all regimes to either improve their state capabilities or face the threat of invasion and fundamental political change. The fate of former great powers such as the Dutch Republic and Spain as well as the crushing defeats of Austria and Prussia manifested very clearly the new situation. Concurrently, many inhabitants were inspired by new thoughts which questioned old economic and social privileges. This combination of increasing external and internal pressures created serious political tensions in the established polities. However, the outcome of these processes diverged between the European states. In many cases, in particular in Germany, Italy and the Low Countries, the old order was swept away by external pressure. In other cases, such as Britain, Denmark and Russia, the existing political systems survived the storm. A third type of outcome was political and institutional change through reforms or internal political upheaval, which occurred in states such as France, Prussia and Sweden. ${ }^{1}$

These varying developments during the period 1792-1815 provide us with an opportunity to explore the connections between warfare, war finance and political change, as well as factors determining a state's capacity to act on the international arena. Such issues have attracted considerable scholarly attention by economists, historians and political scientists who have applied a political economy perspective on the early modern period. One major theme in this body of literature has been to explain institutional developments in Britain after 1688, which led to a financial, and industrial revolution as well as making the British state one of the most powerful in the world. ${ }^{2}$ Concurrently, scholars have tried to explain why large and relatively 
resource rich countries such as France and Spain did not develop along similar lines. ${ }^{3}$ These issues are also related to wider questions about strong and weak states and the determinants of state capacity. ${ }^{4}$

All of these topics are important, but the studies tend to concentrate on the political economy of major states. This means that they do not capture the full extent of the quite complex international state system and the pressures it put on European states during war. The system was full of smaller states, which choice sets differed from the major powers. We can therefore not assume that economic and political processes occurring in major states led to the same outcome in smaller countries. The smaller states' position was on the one hand more flexible since they could use neutrality in times of war in order to pursue mercantile profits. They could also actively seek subsidies from its powerful allies, which reduced the need for internal tax increases. Their position was on the other hand more vulnerable since they could not control the existing alliances and the shifts in policies of the major powers. ${ }^{5}$

In this article, focus is on the case of Sweden, which participated in several wars during the period 1788-1815. These wars led to political changes, which mean that connections between warfare and political transformation in a smaller European state during a major power conflict can be investigated. Furthermore, the Swedish case exhibits some interesting characteristics since policies were shaped by royal absolutism and a national representative institution, the Diet. This institutional structure managed to implement fiscal reforms during the 1780s. However, tensions between the regime and the opposition sharpened in 1805 when Sweden declared war on France and later when Russia attacked the Swedish realm in 1808. The king relied on foreign subsidies as a way to increase revenues without having to resolve existing institutional fiscal problems. Unlike other rulers, he was unwilling to negotiate a deal with the Diet that relinquished his spending control in exchange for greater revenues to fight the war. As a consequence, he was 
unable to mobilize the necessary resources, which led to the loss of Finland and to his dethronement through a coup d'état organized by the elite in March 1809. Absolutism was thus abolished 20 years after it was strengthened in $1789 .{ }^{6}$

Largely contributing to the outcome of these political processes was the structure of the fiscal and monetary system. In the system that emerged in 1789 , the king had total control over how the government's revenue was spent and the income from foreign subsidies. However, the levying of new ordinary and extraordinary taxation had to be approved by the Diet. The decisions of the two main monetary institutions, the Bank of Sweden and the National Debt Office, were also influenced by the Diet. Thus, the regime's access to resources was restricted, which created tensions. The tensions were primarily between the king and oppositional men represented in the Diet and in institutions like the Bank of Sweden and the Debt Office. Consequently, like many absolutist regimes the Swedish fiscal system was characterized by a divided fiscal authority. ${ }^{7}$

According to Jean-Laurent Rosenthal, such divisions were generally distinguished by the king's desires to increase revenue, while the opposition attempted to prevent such increases from taking place in order to limit the king's independence and room for manoeuvre. This made the opposition hesitant to contribute to wars, which in turn created a situation in which the sovereign had to rely on revenue that he could control without the interference of representative bodies. ${ }^{8}$

By drawing on Rosenthal's thesis as well as other insights of recent political economy theories it is possible to tell a novel fiscal story of constitutional change in Sweden. Specifically, the article argues that divided fiscal authority was the key reason why absolutism fell in 1809 . Such an argument contrasts with the previous literature on the period 1789-1809. Many scholars have instead emphasized the poor state of public finances as a crucial factor. The finances have in general been characterized as unstable with constant deficits and shifts between periods of 
excessive increases of liquidity through the issuance of paper money and periods of attempts to create monetary stability by reducing the amount of paper money in circulation. ${ }^{9}$

In order to strengthen the argument about the importance of divided fiscal authority in explaining the outcome in Sweden, comparisons will also be made with other states participating in the Napoleonic Wars. In particular, the Danish case is useful since Denmark-Norway held a similar position in the international state system and it was ruled by an absolute king, but its fiscal system was not characterized by divided fiscal authority. Hence, by comparing the two cases, it is possible to discuss the effects of divided fiscal authority on state capacity as well as political developments during wartime.

\section{The Dynamic Relationship between Resources, War and Politics}

In Jean-Laurent Rosenthal's model of politics and taxation in a European early modern absolutist state, the crown has limited fiscal authority, but the ability to 'spend as it pleases, and public expenditures heavily focused on war'. The crown shares fiscal authority with the elite, which controls parts of the taxation through its influence at different political bodies. These bodies control taxation over geographical areas, groups of individuals, or economic activities.

Furthermore, taxation is not unified, which means that the elite have influence over specific taxation in one part of the economy, while the crown controls taxation in the rest. Normally, the elite influence ordinary revenue while the crown can change excise and tariff rates and regulate property rights. Such a division easily creates situations where the two principal actors debate who should raise resources for joint projects and the elite using its fiscal authority to influence royal policy. The sovereign makes executive decisions and the elite cannot control how he uses his resources. Although the crown and the elite share the returns from winning and losing wars, there is a difference between the expected profits of the king and those of the elite. In other words 
the king has more to gain from warfare. Consequently, there are wars that the sovereign wishes to fight but the elite does not, which creates tensions but also attempts to bargain in order to change the status quo. ${ }^{10}$

As Gary Cox and Mark Dincecco have highlighted, the relationship between sovereigns and elites are also heavily influenced by issues of royal moral hazard and a lack of royal credible commitment to honour pledges relating to spending and debt repayment. Thus, elites fear that kings will spend revenues in reckless or incompetent ways and default on existing debts. They also fear that the king will try and hide crucial fiscal facts and that he will make it difficult for the elite to monitor the king's wars. In order to try and prevent such actions, elites demand preconditions before they agree to provide further funding, while rulers try to avoid such confinements by using for example coercive methods to mobilize necessary resources. ${ }^{11}$

The divided fiscal authority together with issues related to royal moral hazard has a number of implications. First, revenues on the aggregate level will be low. Second, the decision as to which wars are fought depends on the resources that are raised and the willingness of the king and elite to participate in wars. Third, bargaining to change the division and increase government resources can rarely be done without consequences for the distribution of wealth and power. $^{12}$

Although there are many institutional differences between the French and Spanish systems during the early modern period and Swedish absolutism in the late eighteenth century, the model of divided fiscal authority is relevant when analysing the Swedish case mainly because of the fact that the Diet controlled the imposition of new taxes but its members had a very limited ability to influence how the king utilized existing resources. Thus, the king had access to resources that he controlled without having to seek the approval of the Diet. The Swedish system 
in the period 1789-1809 was therefore in practice, even if it was more fiscally centralized than the French and Spanish equivalents, characterized by a divided fiscal authority. ${ }^{13}$

\section{The organization of debt and politics in Sweden prior to 1789}

The political situation in Sweden at the end of the eighteenth century was influenced by the royal coup organized by the king Gustavus III in 1772, which led to the adoption of a new constitution and a significant increase in royal power. Before 1772, key economic and political decisions were made by the Diet and its four - noble, clerical, burgher and peasant - estates. All noble families had a right to send a representative to the Diet, while representatives from the three non-noble estates were elected by their respective constituencies. The change in 1772 meant that the Diet retained its rights to adapt new taxes and legislation, as well as the administration of the Bank of Sweden, but the king gained control of how government resources were spent and his influence over foreign policy and defence increased. Additionally, the king decided when to summon the Diet. $^{14}$

The regime relied on external loans from Amsterdam, Antwerp and Genoa, and limited issuances of bonds on the domestic market to fund existing deficits. ${ }^{15}$ In order to strengthen the administration of this debt a national debt directorate (Riksgäldsdirektionen) was founded in 1778. By creating this institution the regime wanted to separate the administration of the government's debt from the general revenue and expenditure of the state. Specific earmarked taxes were assigned to the directorate for servicing the debt. However, it was not an independent institution since the annual revenue assigned to the directorate was not sufficient to meet all its obligations. The difference had to be covered by the government's regular revenue. ${ }^{16}$ This dependency meant that the regime could easily influence the directorate's decisions, but it also curtailed the regime's manoeuvrability since it could not depend on the directorate to finance 
increases in government spending. In other words, the establishment of the institution did not change the king's dependency on the Diet assigning the necessary resources at times of war.

\section{War and reorganization, 1789-1805}

The 1770s was quite successful for the new regime, but the opposition against the king grew stronger and more vocal in the $1780 \mathrm{~s} .{ }^{17}$ One reason behind the increased tensions was the regime's eagerness to strengthen the realm's status on the international arena through commercial and military means. In 1788, the king decided to start a war against Russia without asking for the Diet's approval. ${ }^{18}$ The king's actions manifest signs of royal moral hazard, since he initiated the war without seeking prior support from the elite and without creating arenas where the elite could monitor developments. Consequently, the directors of the Bank of Sweden were very unwilling to lend money to the king's war efforts. ${ }^{19}$ The situation in 1788 could therefore be characterized as following the logic of a divided fiscal authority: the king desired to fight a war and increase spending, but the available resources which he controlled were not sufficient and the established institutions controlled by the elite, which could increase the available resources were unwilling to provide him with the indispensable funds.

In order to try and circumvent these institutional restrictions, the king was counting on access to international capital from the Dutch Republic and Genoa. Such loans were possible to arrange without seeking the approval from the Diet if the king's own resources were used as collateral. However, the investors were not as eager to lend money as they had been in the past. These fiscal problems forced the king to summon the Diet in 1789. Although this threatened to reduce the king's political autonomy, it was necessary to seek the support of the Diet to receive the crucial resources. Implementing major political changes without summoning the Diet was not a viable option in a Swedish political context. Thus, the Swedish king could not repeat the royal coup in 
Denmark in 1784, which led to increased centralization and control of Danish government finances. ${ }^{20}$ However, the king had a relatively clear plan for what he wanted to achieve during the meeting of the Diet: constitutional changes that would increase his powers and an expansion of the resources available for warfare. Crucially, he could also count on at least some support from the three non-noble estates. By dividing the Diet and using anti-aristocratic sentiments in order to promote a royal agenda, the king managed to push through an amendment to the constitution. Although the opposition tried to voice their grievances, they could not prevent the Diet from approving the changes. ${ }^{21}$ After the amendment had been assented to, focus shifted to the financial problems facing the realm. The king provided detailed accounts of the existing debts as well as the government's demand for additional resources in order make sure that the members of the Diet understood the seriousness in the situation and to emphasize the need for immediate action. ${ }^{22}$ In other words, the king tried to reduce moral hazard by providing valuable information and manifesting his commitment to solving the situation.

After discussing several solutions to the existing problems, it soon became apparent that many members of the Diet supported the idea that the Diet would assume control of the government's debts in return for a pledge from the king to balance budgets in the future. Consequently, a National Debt Office (Riksgäldskontor) under the control of the Diet would be established, which would administer the debt and collect specific taxes to handle all necessary payments. The taxes would ensure that the new office did not have to rely on financial transfers from the government to administer the debt. Furthermore, the office would be given the right to borrow on the international capital markets as well as to issue long-term bonds and small-denomination promissory notes. The promissory notes would circulate simultaneously with notes issued by the Bank of Sweden. ${ }^{23}$ 
According to the Diet's subsequent decision, the new office could only issue a maximum amount of 600,000 riksdaler (herafter abbreviated rdr) in promissory notes, but this sum had been exceeded within a month. As the war continued the issuance of notes exploded. At the end of 1790, the notes amounted to around 8.4 million rdr in nominal value. Torbjörn Engdahl and Anders Ögren have shown that the promissory notes became 'in practice legal tender since they were accepted for all payments, including taxes'. At the same time the Bank of Sweden's notes diminished from circulation. The two notes existed simultaneously and had the same nominal value, but they were not valued at par on capital markets. The price difference indicated that the promissory notes were valued less than the bank's notes. ${ }^{24}$

The establishment of the Debt Office meant that the regime increased the available resources through the issuance of paper money. The office also managed to increase borrowing from Dutch investors. All of these measures strengthened the regime's ability to finance the war effort. Thus, the king had managed to reach his goals with the meeting of the Diet. However, he had to accept that the Diet controlled the administration of the debt and the taxes assigned to service it. The king had also pledged to limit future borrowing, but the fact that liquidity levels could be increased beyond the stated maximum showed that this assurance could be circumvented. The Debt Office was therefore not an independent political body that resisted the king's policies in $1789-1790$.

The meeting of the Diet in 1789 was influenced by issues related to moral hazard. The opposition did not trust the king's pledges, which meant that they tried to limit the king's manoeuvrability by imposing time limits on the new taxation that was crucial to fund the debt. ${ }^{25}$ However, they were not able to stop the war or prevent the changes to the debt system by using their fiscal authority. One main reason for this outcome was the king's ability to use divisions between the estates to promote his agenda. Unlike the situation in Britain in the 1680s, where the 
majority of the elite opposed the actions of the king, some members of the elite in Sweden thought that they could benefit by supporting Gustavus III. ${ }^{26}$ The king's bargaining position was also strengthened by committing to an increase in the elite's power over the debt, which made it more difficult for the elite to resist the changes since it did not threaten their fiscal authority. Thus, it entailed a transfer of resources across the fiscal divide from the government to the Diet. After the war ended in 1790 the regime was occupied with incorporating some of the debts accrued during the war into the national debt. This was achieved at a meeting of the Diet in 1792. ${ }^{27}$ As is shown in table 1 , the government's total debt level stabilized after 1792 . However, these figures hide a number of developments during the 1790s. The foreign debt, which was steady around 10 million rdr, was mainly owned by investors in Amsterdam, Antwerp and Genoa, while the domestic debt was principally divided into two parts: long-term bonds and promissory notes. In 1800, the issued bonds were valued at around 2.5 million rdr, which meant that they made up less than ten per cent of the total debt. The largest and expanding part of the domestic debt consisted of promissory notes. Hence, like in France during the 1790s when the revolutionaries used assignats to finance the government's deficits, the increase in the Swedish domestic debt during the 1790 s can largely be attributed to the issuance of promissory notes. ${ }^{28}$ [Place Table 1 here]

The increase in promissory notes had several implications. First it showed that the regime had found a way to circumvent the commitments made in 1789 to limit existing deficits. Thus, the directors of the Debt Office were unable to control the regime's actions, which only increased the opposition's fears about the king's intentions. Consequently, the problems of royal moral hazard persisted. However, the reliance on paper money also created administrative problems for the Debt Office. The promissory notes did not bear any interest, but could not be used for international transactions. Since the Debt Office received most of its revenue in promissory notes 
it could not directly utilize this income to pay the interest on the foreign debt. In 1800 , for example, the office's revenue totalled 1,444,281 rdr, of which only 83,521 were in specie and $1,360,760$ in promissory notes. The expenses on the other hand amounted to $1,668,975 \mathrm{rdr}$, of which 860,131 were in specie and 808,844 in notes. In order to pay the international creditors the Debt Office had to pay high fees to transfer the notes into international bills of exchange. In 1800 , the costs associated with international transactions amounted to $717,766 \mathrm{rdr}$ or 43 per cent of the office's expenditure. This was much higher than the interest payments on the foreign debt $(556,583 \mathrm{rdr})$ or on the domestic debt $(119,969 \mathrm{rdr}) .^{29}$

[Place Table 2 here]

As is shown in table 2, the Debt Office controlled around 28 per cent of state revenue, while the government commanded the rest. Although the government numbers are estimates and not all assets are included, it gives some indication of the available resources that could be utilized by state institutions. If the Debt Office's expenditure in 1800 is related to the state's total revenue, it shows that 31.9 per cent of government revenue was used to service the national debt in Sweden. [Place Table 3 here]

By comparison, the Danish state, which debt structure is highlighted in table 3 , managed to reduce its debt during the 1790s. However, an economic downturn in 1799 led to a sharp growth in debt levels in 1800, mostly as a consequence of increasing issues of bank notes. That year foreign loans comprised 21.8 per cent, domestic long-term bonds 38.1 per cent and bank notes 40.1 per cent of the total debt. Concurrently, government revenue amounted to $10,656,635$ rigsdaler (hereafter abbreviated rgd) in 1800, while the costs associated with the administration of the debt totalled 4,239,092 rgd. ${ }^{30}$ Thus, the Danish state used 39.8 per cent of its income to finance the national debt, while Sweden used 31.9 per cent. 
The promissory notes created problems for the Swedish Debt Office in the late 1790s, but they were exacerbated by an economic crisis in Hamburg in 1799, which spread to both Denmark and Sweden. The crisis led to a reduction in liquidity, which in turn made it difficult to handle the interest payments on the external loans. The Debt Office tried to solve the lack of specie assets by borrowing on the international capital markets, but no European banker was willing to organize a new loan. ${ }^{31}$ Concurrently, many inhabitants expressed dismay with the increasing numbers of promissory notes and their unstable value. The economic crisis was therefore becoming a political threat to the king and his claims to be a champion of stability. ${ }^{32}$

Although it was theoretically possible for the regime to continue issuing paper money, it was creating political problems that could not be ignored. The only viable political alternative was to convene the Diet in 1800 with the purpose of restructuring the debt. At the meeting, the new king Gustavus IV Adolphus proposed that only notes issued by the Bank of Sweden should be legal tender and that the promissory notes be removed from circulation. ${ }^{33}$ These statements can be seen as an attempt to decrease royal moral hazard by stressing the need to reduce uncertainty in the currency system.

Many members of the Diet agreed on the necessity of rescheduling the debt, but there were differing views on the terms with which the promissory notes should be removed from circulation. After long-drawn out negotiations it was decided that the notes would be withdrawn by exchanging them at a discount with notes which were convertible into silver. The discount was set at 16.6 per cent, which was significantly lower than the market value. It was also agreed that a fund of silver would be established, with the aid of a temporary new tax on wealth, in order to finance the exchange of notes. ${ }^{34}$

After the meeting of the Diet, the regime tried to implement the decisions, but they encountered several problems such as a deteriorating value of the promissory notes, which made 
the proposed exchange a very expensive affair for the state. One solution to the problem would have been to summon the Diet again, but that would have caused a severe loss of political prestige. Instead, the king decided to go ahead with the proposed exchange, but the terms differed from the original plan. According to the new plan the exchange would take place at a 33.3 per cent discount, which was more beneficial for the state but worse for the holders of the notes. He legitimized this action by referring to a proviso that was given to him by the three non-noble estates. In the proviso, the king was authorized to take whatever measure necessary to achieve the exchange as long as the Diet's taxation privileges were respected. In order to strengthen the silver fund and manifest his commitment to the exchange, the king decided to mortgage the Swedish possession in Wismar to the duke of Mecklenberg-Schwerin. Together with the assets from a loan in Leipzig in 1802, the resources were deemed to be sufficient to start the exchange in 1803. At the same time the temporary wealth tax was revoked, which meant that the exchange went ahead without the income from any new taxes. ${ }^{35}$

The effects of the decisions in the period 1800-03 can be seen in the Debt Office's books in 1805. Total net debt had been dramatically decreased from 29.6 million rdr in 1800 to 13.2 million rdr in 1805 . The size of the foreign debt was still around 10 million, but the domestic net debt had been cut to around 3.3 million. The changes also had an effect on the Debt Office's revenue and expenditure. The revenue amounted to 1,740,614 rdr, which was significantly higher than 1800, but most crucially, the income was now easier to utilize when making international transactions since it had a determined value in silver. The office only had to spend 129,981 rdr on international transaction costs compared with 717,766 in 1800. The expenditure was thus reduced to $1,163,810 \mathrm{rdr}$, which meant that the office generated a surplus of $576,804 \mathrm{rdr}$ in $1805 .^{36}$ As a consequence, the state's overall debt burden was reduced from 31.9 per cent in 1800 to 21.6 per cent in $1805 .^{37}$ 
The Danish state, which also experienced increasing issues of bank notes following the crisis in 1799, did not reduce the number of notes in circulation. The number of notes therefore continued to rise. At the same time, the state increased taxes while deferring some payments on the foreign loans. ${ }^{38}$ Consequently, in 1805 government revenue had risen to 15,641,286 rgd while the costs associated with its debt shrunk to $3,456,079$ rgd. ${ }^{39}$ Denmark had thus managed to reduce its debt burden to 22.1 per cent by increasing its revenues. The increases protected the Danish reputation as a credible creditor that did not default on issued bank notes or other obligations. ${ }^{40}$ In Sweden on the other hand the divided fiscal authority meant that it was difficult to reach agreements about permanent tax increases. Instead the king was forced primarily to use resources he controlled to solve the existing challenges. The solution, however, did not remove the problems of moral hazard since the king deviated from the plan which was approved by the Diet.

Nonetheless, when considering the improvement in the Debt Office's finances, it is evident that the regime had achieved its goal without surrendering any political autonomy. The exchange of the promissory notes in Sweden did not become as costly for the state's finances as the first decision indicated, since the regime could use its support from the non-noble estates to take the necessary steps to organize an exchange when the original plan failed. The regime had thus yet again been able to divide the elite for its own benefit. However, the regime's relative success can also be explained by the realization among the population that something had to be done about the promissory notes. In other words, very few actors supported a continuation of paper money, even if the exchange meant a de facto default on part of the debt. Since the established exchange rate did not seriously deviate from the market value of the notes, the losses that note holders experienced were in reality quite marginal. Additionally, the regime's actions were relatively successful because the regime was forced to use its own resources to deal with an issue that, at least theoretically, was the responsibility of the Diet. 
The strengthening of the Debt Office's finances led to a drastically diminishing market for government bonds. In 1803, a total of 1,015 bonds valued at 781,050 rdr were sold. Two years later only 20 bonds valued at 27,050 rdr were sold. ${ }^{41}$ The main reason for this fall in volume was a decision by the Debt Office in 1804 to suspend further sales of bonds. The directors argued that the office's improved balance sheet and the increased holdings of assets in specie made it unnecessary to continue issuing bonds on the domestic market. ${ }^{42}$

\section{Debt, War and Political Change, 1805-1809}

The fiscal improvements after 1803 increased the king's autonomy, which was used to play a more active part in German politics and to oppose Napoleon. Without consulting the Diet, Swedish troops were shipped to Swedish Pomerania when Sweden declared war on France in 1805. The cost of maintaining troops in Pomerania was primarily financed with British subsidies. Consequently, around $£ 20,000$ a month was transferred from Britain to Sweden. ${ }^{43}$

Since Sweden only utilized a small 10,000 men army, the British subsidies covered almost the entire war effort. The king did therefore not have to summon the Diet in order to seek funding or stop the exchange of promissory notes. ${ }^{44}$ Foreign subsidies, which the king controlled without interference from the Diet, can thus be interpreted as a way for an absolute regime in a smaller state to participate in wars without having to deal with the political problems associated with a divided fiscal authority, or fight limited wars even if the elite refuse to contribute any resources to them. Such manifestations of political autonomy lead, however, to increasing political tensions since it augments royal moral hazard.

The king's strategy encountered problems following Napoleon's victories against Austria and Prussia. The situation deteriorated even further in 1808 when Russian forces crossed the border into Finland. A month later Denmark, which had sided with France in the Anglo-French 
conflict, declared war. ${ }^{45}$ The military developments meant that Sweden had to send troops to several parts of the realm. Although a new subsidy treaty was signed with Britain that gave Sweden $£ 100,000$ a month, it was not sufficient to meet the new threats. The Swedish government was therefore forced to also mobilize resources domestically. According to the constitution, the king could impose an emergency war tax, which all households in the realm had to pay, without summoning the Diet. He could also request limited emergency loans and advances from both the Debt Office and the Bank of Sweden. ${ }^{46}$ The king also decided to temporarily cancel interest payments to the realm's creditors in Amsterdam, Antwerp and Genoa. $^{47}$

Although the subsidies, advances and the new war tax together with the cancellation of payments increased the available resources, they were not sufficient to cover the costs of the war. The king was therefore forced to send funding requests to the Debt Office where he offered future government revenue as collateral. By requesting funds, the king was trying to access resources that the Diet controlled but without having to summon the Diet. In order to manage such a strategy he stressed the pressing situation that the realm faced, but he also focused on the continuing exchange of the promissory notes. ${ }^{48}$ Consequently, he was not going to destroy the fiscal achievements which had been made during his reign by printing notes on a large scale or drastically increasing the debt through other means. By stressing his commitment to the decisions in 1800 and the fiscal prudence that were associated with them he tried to reduce royal moral hazard. He thereby hoped to avoid having to summon the Diet. Thus, he wanted to protect his political autonomy. This means that the absolute king pursued policies that Mark Dincecco has associated with regimes characterized by centralized institutions and limited government. ${ }^{49}$

Although the directors of the Debt Office expressed increasing alarm about the requests and warned of the dire consequences if the king relied on advances from the office, they thought 
it was their duty as subjects to help in the difficult circumstances. ${ }^{50}$ The directors of the Debt Office were thus treading a fine line between helping the realm's war effort and protecting the office's finances and the Diet's fiscal powers. The end result of such conflicting interests was a lukewarm response to the king's request: they could not outright say no, but they could not give all available resources to the king either. The divided fiscal authority led in other words to a reduction in aggregate revenue. Consequently, they decided to give the king limited advances and they also started to sell bonds, but the domestic bond market was weaker in 1808 than it had been in 1803 . In 1808 , a total of 304 bonds valued at 259,955 rdr were sold. ${ }^{51}$

[Place Table 4 here]

The effects of these policies can clearly be seen in table 4, which shows that the debt had not risen dramatically from 1805 to 1808 . The biggest part of the increase was caused by a rise in the number of promissory notes, which predominantly occurred in 1808 . These notes were used to finance the advances to the state. Several Swedish scholars have emphasized that this increase in notes meant a de facto return to paper money. ${ }^{52}$ However, the increases should not be overemphasized, especially when compared to the situation in 1792 or 1800 . Moreover, as can be seen in table 5 the Swedish currency was relatively stable against leading European currencies, which signals that no extreme increase in the number of notes took place. Furthermore, the Debt Office was able to meet its financial obligations despite the loss of tax revenue from Finland. ${ }^{53}$ [Place table 5 here]

In order to understand the actions of the regime in 1808 it is necessary to create a picture of the total revenue, including subsidies, advances and loans, that the state had at its disposal to wage the war. Table 6 manifests that roughly 55 per cent of the revenue originated from resources that the regime controlled without interference from the Diet (subsidies, ordinary and extraordinary revenue, exchange fund) and that the rest were advances and loans from institutions that were 
controlled by the Diet. Nonetheless, some of these emergency advances, such as the loan from the Bank of Sweden, were provided for by the Diet at previous meetings and were therefore impossible to decline in 1808 . The remaining resources had to be negotiated. However, since over 30 per cent of the revenue originated from British subsidies, the regime could limit their requests to the Debt Office.

[Place table 6 here]

The numbers strengthen the interpretation that the regime was focusing on using resources that it controlled together with limited loans and advances from the Debt Office without imposing new taxes. Although the regime used the war tax, the sums that this generated only represented around 6 per cent of the revenue. Consequently, it is difficult to argue that the regime desperately tried all measures to mobilize resources to fight the realm's enemies. The logic of the divided fiscal authority together with the king's attempts to protect his autonomy made such attempts very difficult.

A comparison with the situation in Denmark, which was involved in a war with Britain and Sweden, reinforces this picture. In Denmark the state had managed to almost double total government revenue from around 10 million in 1800 to almost 20 million in 1808 , while the total debt rose from 48.2 million rgd in 1800 to 75.9 million in 1808. In 1808, the debt comprised 15 per cent foreign debt, 36 per cent long-term domestic debt and 49 per cent bank notes. This meant that the bank notes had increased in volume, while the international debt had been reduced. As a result, the cost of administering the debt fell to 16.1 per cent of total government revenue in $1808^{54}$

The big difference between Denmark and Sweden was thus the ability to increase tax revenues in the period 1800-1808. In Sweden, the king could not raise taxes because he did not want to summon the Diet, but the Danish king did not face the same fiscal and institutional 
constraints. He could therefore increase taxes without meeting the same political resistance as his Swedish counterpart. Mark Dincecco has shown statistically that such constraints played a crucial role in determining the amount of resources that European powers could mobilize. Centralized and limited governments such as Britain could mobilize more than centralized and absolutist states such as Denmark, which in turn could muster more than fragmented and absolutist states such as Spain. ${ }^{55}$

The weakness in the Swedish regime's strategy became apparent in January and February 1809, when military commanders started to complain about a lack of funds. They pointed to the fact that they could not feed the troops or care for the wounded. ${ }^{56}$ Before the king could find new ways to mobilize resources, he was arrested in Stockholm by a number of disgruntled officers in March 1809. Subsequently, the king was dethroned, the Diet summoned, a new constitution was adopted that guaranteed the Diet's political influence and negotiations were initiated with Russia that led to the cessation of Finland in exchange for peace. ${ }^{57}$

Swedish historians have primarily explained the events of 1809 by pointing to the king's increasing loss of legitimacy combined with a growing dissatisfaction among the elite. ${ }^{58}$ There is no doubt that such factors played an important role and that many members of the elite resisted the king's war policy during the final years of absolutism. Many historians have also pointed to fiscal problems as a cause. Klas Nyberg has argued that Sweden 'was almost bankrupt' by 1809. ${ }^{59}$ Such arguments are very problematic, since it was not a lack of resources as such or excessive debt levels that caused the fall of absolutism. Instead one major answer can be found in the divided fiscal authority, which reduced the resources that could be mobilized for warfare.

The resolution to the problems of divided fiscal authority and royal moral hazard differed in Sweden from how this process generally has been explained by scholars. According to Hoffman and Rosenthal, changes in a system of divided fiscal authority occur when the kings 
derive more benefits from higher tax revenue than controlling government spending. They argue that such a change in preferences occurred during the Napoleonic Wars when penalties for sovereigns 'who lost wars because they lacked sufficient funds' were increased. Mark Dincecco on the other hand has stressed a different timing in the process. He argues that fiscal centralization was established before representative institutions gained budgetary authority. Consequently, centralization eventually led to stronger checks and balances in the system. ${ }^{60}$ In the Swedish case, the king resisted change even though there were problems financing the war effort. Instead of summoning the Diet or disregarding established rules and privileges, like many absolutist rulers had done in the past, the king attempted to protect his position by committing to fiscal and monetary prudence and only utilize revenue he could control. The royal position meant that it was the elite who had to act in order to change the status quo. However, they had no formal institutional path to utilize. Their only available option was overthrowing the king through the use of violence. After the coup, they could establish a new political order that guaranteed regular meetings of the Diet, which in turn reduced fiscal divisions and increased budgetary authority. Consequently, it became impossible for the new king to start wars without first gaining the approval of the Diet, but the government would also have more access to resources. The military campaign in 1813-14 was thus approved and financed at a meeting of the Diet in 1812. However, as Jan Luiten van Zanden and Arthur van Riel have pointed out such budgetary authority was not fully effective until the budget was reviewed and approved on a yearly basis. ${ }^{61}$

\section{Conclusion}

This article has shown that a model of divided fiscal authority can help us to explain why the Swedish system of absolutism first seemed more flexible and able to implement reforms than the ancien régime in France or Spain, but also why this adaptation to changing circumstances did not 
work in the first decade of the nineteenth century. The divided fiscal authority structured the government debt, but also the political actions taken by both the regime and the elite. The struggles between the two parties increased during the Napoleonic Wars when it became more difficult for many European states, including Sweden, to borrow on international capital markets in a way they had done prior to 1792. At the same time, the resources generated from the free flow of trade diminished as a result of blockades and restrictions. ${ }^{62}$ These changes forced many regimes to increase domestic taxation as a way of mobilizing more resources. Britain's introduction of an income tax in 1799 or Denmark's tax increases in the early 1800 s can be seen as signs of this trend. ${ }^{63}$ In Sweden it created a situation in which more resources had to be mobilized domestically, which in turn led to increasing struggles concerning the division of costs. The tensions between the regime and the elite after 1805 can therefore be seen as a reaction to a structural need to rely more on internal taxation and less on international capital. However, some of this tension was reduced by foreign subsidies, which made it possible for the regime to protect its political autonomy and avoid the problems associated with a divided fiscal authority. The Swedish regime was thus facing a different situation in 1808 than during the Russian-Swedish war in 1788-90. Unlike states such as Britain and Denmark, which had an undivided fiscal authority, Sweden's regime experienced more difficulties to cope with these new challenges.

The Swedish case shows that the model of divided fiscal authority is generally applicable to smaller European states and that it can explain the outcome of key fiscal and political processes in these states. However, the analysis has also shown that there are a number of significant aspects that have not been incorporated into existing analytical frameworks. ${ }^{64}$ First, the ability of a regime to use divisions within the elite to bargain deals and increase aggregate revenue without changing the fundamental division of fiscal authority have not been fully addressed. Second, the seeming generosity of a regime to provide resources to solve a problem 
that theoretically is the elite's responsibility in order to circumvent blockages and reach agreements have not been discussed. Thus, a king could transfer resources to the elite's side in order to gain support instead of trying to extract more resources from areas which he controlled. Third, not only representative institutions attempt to limit state spending. As the Swedish case highlights, efforts to reduce moral hazard while protecting the sovereign's political autonomy could lead to a situation in which an absolute king was forced to commit to policies of fiscal frugality. Fourth, the issue of relative risk/opportunity in the international state system has not been fully explored in existing models. Being located in a system which was controlled by major states meant on one hand that the military risks were higher for smaller states. For example key parts of a smaller state's territory could be occupied by foreign forces. On the other hand, significant resources such as subsidies could be extracted from the major powers, which reduced the need to use domestic revenues and downgraded the necessity to deal with a divided fiscal authority. Subsidies could thereby enhance state capacity, but also make it more likely for sovereigns to initiate wars even if they did not have the necessary domestic resources at their disposal.

These findings mean that we need to broaden the analysis of the international state system and the determinants of strong and weak states by examining major powers and smaller states, as well as domestic and international factors. Smaller states could hold a peripheral and therefore relatively vulnerable position internationally, but be fiscally centralized. The case of Denmark is an example how a smaller absolutist state could manifest state capacity such as being able to increase taxation and maintain its relationship with the international capital markets despite increasing military pressures. However, like the Swedish case, a peripheral position in the international state system could also be combined with a centralization of resources and internal divisions of fiscal authority, which reduced the capacity to mobilize resources and the ability to 
act. Thus, the weakness was not so much a result of relative economic poverty or incapacitated state institutions, but rather political constraints caused by struggles between the major actors in the system. This variance means that Acemoglu's as well as Besley and Persson's concepts of strong and weak states do not fully capture the wide array of cases in the European state system. One way of increasing our understanding of how this system functioned and its inherent logic is to include more small states in future analyses since they provide us with clues regarding the available policy options as well as the limits and consequences of these options. Such a widening of cases will lead to a better comprehension of the dynamic relationship between warfare, state capacity and political developments in Europe and around the world. 
Table 1: Overview of the Swedish government debt 1790-1800 in riksdaler

\begin{tabular}{|l|l|l|l|}
\hline & Foreign net debt & Domestic net & Total net debt \\
\cline { 2 - 3 } & & debt & \\
\hline 1790 & $9,531,150$ & $11,731,785$ & $21,262.935$ \\
\hline 1792 & $12,745,140$ & $15,615,245$ & $28,360,385$ \\
\hline 1794 & $11,549,335$ & $16,756,383$ & $28,305,718$ \\
\hline 1796 & $10,471,674$ & $17,598,344$ & $28,070,018$ \\
\hline 1798 & $10,615,276$ & $18,053,003$ & $28,668,279$ \\
\hline 1800 & $10,336,591$ & $19,291,707$ & $29,628,298$ \\
\hline
\end{tabular}

Source: Åmark (1961, pp. 644-8). 
Table 2: The relationship between government revenue and Debt Office revenue in 1800

\begin{tabular}{|l|l|l|}
\hline & Revenue & Proportion of total in \\
\cline { 2 - 3 } & & percentage \\
\hline Ordinary and & $3,384,917$ & 64.8 \\
government revenue & & \\
\hline Temporary & 395,461 & 7.6 \\
government revenue & & \\
\hline Debt Office revenue & $1,444,281$ & 27.6 \\
\hline Total & $5,224,659$ & 100.0 \\
\hline
\end{tabular}

Source: SNA, Statskontoret, Kansliet, Svea Rikes stat, GIE, vol. 8; Riksgäldskontoret, Bokslutskontoret, Skilda räkenskaper G12B, Diverse uppställningar och sammandrag 1792-1814, vol. 8349. 
Table 3: Overview of the Danish government debt 1790-1800 in rigsdaler

\begin{tabular}{|l|l|l|l|}
\hline & Foreign gross debt & Domestic gross debt & Total gross debt \\
\hline 1790 & $16,844,164$ & $31,121,433$ & $47,965,597$ \\
\hline 1792 & $16,282,573$ & $28,281,821$ & $44,564,394$ \\
\hline 1794 & $15,470,722$ & $27,363,808$ & $42,834,530$ \\
\hline 1796 & $14,377,353$ & $28,321,106$ & $42,698,459$ \\
\hline 1798 & $12,149,577$ & $28,686,541$ & $40,836,118$ \\
\hline 1800 & $10,536,429$ & $37,724,088$ & $48,260,517$ \\
\hline
\end{tabular}

Source: DNA, Finanskollegiet, Protokol for tabellariske oversigter indtægter og udgifter 1784-1806, vol. 1036; Wilcke (1929, p. 253). 
Table 4: Swedish net government debt in 1808

\begin{tabular}{|l|l|}
\hline Foreign debt & $10,076,351$ \\
\hline Domestic debt excluding promissory notes & $1,238,983$ \\
\hline Promissory notes (their value in specie) & $4,318,516$ \\
\hline Total debt in specie & $15,633,850$ \\
\hline
\end{tabular}

Source: SNA, Riksgäldskontoret, Bokslutskontoret, Skilda räkenskaper, vol. 8350; Koncepthuvudböcker år 1808, vol. 7018. 
Table 5: Monthly exchange rates on Hamburg. SEK per 100 marks 1806-1808

\begin{tabular}{|l|l|l|l|l|l|l|l|l|l|l|l|l|}
\hline & Jan & Feb & Mar & Apr & May & Jun & Jul & Aug & Sep & Oct & Nov & Dec \\
\hline $\mathbf{1 8 0 6}$ & 34.78 & 34.87 & 35.04 & 34.96 & 35.92 & 35.66 & 35.92 & 35.66 & 35.66 & 36.01 & 37.15 & 39.95 \\
\hline $\mathbf{1 8 0 7}$ & 39.07 & 39.25 & 37.67 & 37.67 & 37.41 & 37.85 & 36.97 & 37.41 & 38.37 & 38.37 & 39.42 & 38.90 \\
\hline $\mathbf{1 8 0 8}$ & 38.37 & 37.76 & 37.15 & 36.45 & 36.45 & 36.45 & 36.45 & 36.45 & 37.15 & 39.25 & 39.95 & 39.95 \\
\hline
\end{tabular}

Source: Lobell (2010, p. 319). 
Table 6: The Swedish state's total revenue in 1808

\begin{tabular}{|l|l|l|}
\hline & Revenue & Percentage \\
\hline British subsidies & $5,493,753$ & 33.5 \\
\hline New loans from the Debt & $3,413,333$ & 20.8 \\
\hline Government ordinary and & $3,344,497$ & 20.4 \\
\hline extraordinary taxation & & \\
\hline Debt Office ordinary revenue & $1,599,650$ & 9.9 \\
\hline Advance for the new war tax & $1,000,000$ & 6.1 \\
\hline Emergency loan from the & $1,000,000$ & 6.1 \\
\hline Bank of Sweden & & 3.2 \\
\hline Advance from the Exchange & 530,891 & 100.0 \\
\hline Fund & & $16,383,955$ \\
\hline Miscellaneous revenue & & \\
\hline Sotal & & \\
\hline
\end{tabular}

Source: SNA, Riksgäldskontoret, Bokslutskontoret, Koncepthuvudböcker år 1808, vol. 7018; Statskontoret, Kansliet, Svea Rikes stat GIE, vol. 16; Åmark (1961, p. 855). 


\section{Footnotes}

${ }^{1}$ Bonney (1995, pp. 315-390); Scott (2006, pp. 244-354); Bell (2007); Dincecco (2009b, pp. 51-4).

${ }^{2}$ See for example O’Brien (1988); Brewer (1989); North and Weingast (1989); Stasavage (2007); Cox (2011);

Pincus and Robinson (2011).

${ }^{3}$ See for example Thompson (1994); White (1995); Hoffman and Rosenthal (1997); Rosenthal (1998); Hoffman and Rosenthal (2000); Dincecco (2009a); Dincecco (2009b); Cardoso and Lains (2010); Dincecco (2010).

${ }^{4}$ Acemoglu (2005); Besley and Persson (2010).

${ }^{5}$ See for example Feldbæk (1983, pp. 7-20); Scott (2006, p. 54).

${ }^{6}$ Barton (1986, pp. 165-71); Alm (2003, pp. 25-9); Tandefelt (2008, pp. 233-7).

${ }^{7}$ Landberg (1932, pp. 110-58).

${ }^{8}$ Rosenthal (1998).

${ }^{9}$ See for example Dahlström (1942); Åmark (1961); Ahlström (1974); Ahlström (1989); Nyberg (2010); Schön (2010, pp. 166-7).

${ }^{10}$ Rosenthal (1998, pp. 67-70).

${ }^{11}$ Dincecco (2009a, pp. 31-6; Dincecco (2009b, pp. 54-5); Cox (2011, pp. 138-43).

${ }^{12}$ Hoffman and Rosenthal (1997, pp. 34-53); Rosenthal (1998, pp. 71-84); Dincecco (2009b, p. 55).

${ }^{13}$ Glete (2002, pp. 189-212) shows how the centralization process started already in the sixteenth century. However, all institutions were not under royal control. Schön (2010, pp. 166-7) misunderstands the relationship between the king and the Bank of Sweden/the National Debt Office when he states that the sovereign had 'direct access' to the institutions.

${ }^{14}$ Hallendorff (1920, pp. 36-51); Barton (1986, pp. 82-5); Alm (2003, pp. 23-9); Tandefelt (2008, pp. 52-113).

15 Åmark (1961, pp. 234-7); Ahlström (1974, pp. 18-20); Riley (1980, p. 146).

16 Åmark (1961, pp. 624-5).

${ }^{17}$ Landberg (1932, pp. 77-87).

${ }^{18}$ Barton (1986, pp. 154-6); Müller (2011, pp. 143-4).

${ }^{19}$ Hallendorff (1920, pp. 138-45, 165-8); Dahlström (1942, pp. 30-33); Åmark (1961, pp. 844-5).

${ }^{20}$ The Danish reforms are discussed in Johansen (1968, pp. 141-4). 
${ }^{21}$ Landberg (1932, pp. 90-109).

22 Åmark (1961, pp. 257-8).

${ }^{23}$ Dahlström (1942, pp. 79-119); Åmark (1961, pp. 633-41).

${ }^{24}$ Engdahl and Ögren (2008, pp. 77-9). See also Åmark (1961, pp. 644-5).

${ }^{25}$ Åmark (1961, p. 259); Gärdebo (2009, pp. 53-6).

${ }^{26}$ The importance of elite loyalties and interests are highlighted by Stasavage (2007); Cox (2011); Pincus and Robinson (2011).

${ }^{27}$ Åmark (1961, pp. 263-5, 644-9).

${ }^{28}$ The assignats are discussed in White (1995, pp. 234-41).

${ }^{29}$ Swedish National Archives, Stockholm (hereafter abbreviated SNA), Riksgäldskontoret, Bokslutskontoret, Skilda räkenskaper G12B, Diverse uppställningar och sammandrag 1792-1814, vol. 8349.

${ }^{30}$ Danish National Archives, Copenhagen (hereafter abbreviated DNA), Finanskassedirektionen, Hoved- og Kontrabogholderkontoret, Hovedindtægtsbøger 1784-1816, 1800; Hovedudgiftsbøger for Civiletaten 1784-1816, 1800; Finanskollegiet, Protokol for tabellariske oversigter indtægter og udgifter 1784-1806; Wilcke (1929, p. 253).

${ }^{31}$ SNA, Riksgäldskontoret, Huvudarkivet, Fullmäktiges hemliga protokoll, A2A, vol. 4379, 11 March, 20 May, 15 July 1799. See also Feldbæk (1993, p. 148).

${ }^{32} \operatorname{Alm}$ (2003, pp. 31-33); Winton (2009, pp. 81-97).

${ }^{33}$ SNA, Hemliga utskottets protokoll 1800, vol. R3665, 3 March 1800.

${ }^{34}$ Landberg (1932, pp. 131-2); Åmark (1961, pp. 291-2).

${ }^{35}$ Landberg (1932, pp. 153-154); Åmark (1961, pp. 296-8); Weber (2008, pp. 240-52).

${ }^{36}$ SNA, Riksgäldskontoret, Bokslutskontoret, Skilda räkenskaper G12B, vol. 8350.

${ }^{37}$ SNA, Statskontoret, Kansliet, Svea Rikes stat GIE, vol. 13; Riksgäldskontoret, Bokslutskontoret, Skilda räkenskaper G12B, vol. 8350.

${ }^{38}$ Svendsen and Hansen (1968, pp. 84-7).

${ }^{39}$ DNA, Finanskassedirektionen, Hoved- og Kontrabogholderkontoret, Hovedindtægtsbøger 1784-1816, 1805 and Hovedudgiftsbøger for Civiletaten 1784-1816, 1805.

${ }^{40}$ Bochove (2008, pp. 101-25, 142-53). 
${ }^{41}$ SNA, Riksgäldskontoret, Bokslutskontoret, Avräkningsböcker över obligationer för inrikeslån 1801-1806, vol. 8275.

${ }^{42}$ SNA, Riksgäldskontoret, Huvudarkivet, Fullmäktiges protokoll, A1A, vol. 4069, 16 and 23 July 1804.

43 Åmark (1961, pp. 852-3); Barton (1986, pp. 265-7).

44 Åmark (1961, p. 645).

${ }^{45}$ Barton (1986, pp. 275-83).

46 Åmark (1961, pp. 309, 854).

${ }^{47}$ SNA, Riksgäldskontoret, Huvudarkivet, Fullmäktiges protokoll vol. 4077, 29 February 1808.

${ }^{48}$ SNA, Riksgäldskontoret, Huvudarkivet, Fullmäktiges protokoll vol. 4078, 28 July, 24 November 1808.

${ }^{49}$ Dincecco (2010).

${ }^{50}$ SNA, Riksgäldskontoret, Huvudarkivet, Fullmäktiges protokoll vol. 4078, 28 July, 24 November 1808.

${ }^{51}$ SNA, Riksgäldskontoret, Bokslutskontoret, Avräkningsböcker över obligationer för inrikeslån 1806-1808, vol. 8277.

52 Ahlström (1989, p. 111); Engdahl and Ögren (2008, p. 78); Nyberg (2010, p. 29).

${ }^{53}$ SNA, Riksgäldskontoret, Bokslutskontoret, Skilda räkenskaper, vol. 8350; Koncepthuvudböcker år 1808, vol. 7018.

${ }^{54}$ DNA, Finanskassedirektionen, Hoved- og Kontrabogholderkontoret, Hovedintægtsbøger 1784-1816, 1808;

Hovedudgiftsbøger for Civiletaten 1784-1816, 1808; Finanskollegiet, Efterretninger vedrørende statsgælden 1784-

1814, vol. 1071; Wilcke (1929, p. 253).

${ }^{55}$ Dincecco (2009b, pp. 61-80).

${ }^{56}$ SNA, Riksgäldskontoret, Huvudarkivet, Fullmäktiges protokoll vol. 4079, 6 and 9 February 1809. See also Hårdstedt (2002, pp. 118-23).

${ }^{57}$ Hemström (2005, pp. 41-8, 56-149); Sundin (2006, pp. 47-113, 193-227).

${ }^{58}$ See for example Alm (2003); Hemström (2005); Sundin (2006).

${ }^{59}$ Nyberg (2010, p. 17).

${ }^{60}$ Hoffman and Rosenthal (2000); Dincecco (2009b).

${ }^{61}$ Barton (1986, pp. 311-26); Zanden and Riel (2004, p. 175).

${ }^{62}$ Riley (1980, pp. 195-203); O’Rourke (2006). 
${ }^{63}$ O’Brien (2009, pp. 174-84).

${ }^{64}$ See for example Rosenthal and Hoffman (1997); Rosenthal (1998); Dincecco (2009a); Dincecco (2009b); Cox (2011). 


\section{References}

Acemoglu, D. (2005). Politics and Economics in Weak and Strong States. Journal of Monetary Economics 52, pp. 1199-1226.

Ahlström, G. (1974). Studier i svensk ekonomisk politik och prisutveckling 1776-1802. Lund: Studentlitteratur.

Ahlström, G. (1989). Riksgäldskontoret och Sveriges statsskuld före 1850-talet. In E. Dahmén (ed.), Upplåning och utveckling. Riksgäldskontoret 1789-1989. Stockholm:

Riksgäldskontoret.

Alm, M. (2003). Royalty, Legitimacy and Imagery. The Struggles for Legitimacy of Gustavian Absolutism, 1772-1809. Scandinavian Journal of History 28 (1), pp. 19-36.

Åmark, K. (1961). Sveriges statsfinanser 1719-1809. Stockholm: Norstedt.

Barton, H.A. (1986). Scandinavia in the Revolutionary Era, 1760-1815. Minneapolis, MN: Minnesota University Press.

Bell, D.A. (2007). Napoleon's Europe and the Birth of Modern Warfare. London: Bloomsbury. Besley, T. and Persson, T. (2010). State Capacity, Conflict, and Development. Econometrica 78 (1), pp. 1-34.

Bochove, C. van (2008). The Economic Consequences of the Dutch. Economic Integration around the North Sea, 1500-1800. Amsterdam: Aksant.

Bonney, R. (1995). The Struggle for Great Power Status and the End of the Old Fiscal Regime. In R. Bonney (ed.), Economic Systems and State Finance. Oxford: Oxford University Press.

Brewer, J. (1989). The Sinews of Power. War, Money and the English State, 1688-1783. London: Unwin Hyman.

Cardoso, J.L. and P. Lains (2010). Introduction: Paying for the Liberal State. In J.L. Cardoso and 
P. Lains (eds), Paying for the Liberal State. The Rise of Public Finance in NineteenthCentury Europe. Cambridge: Cambridge University Press.

Cox, G.W. (2011). War, Moral Hazard, and Ministerial Responsibility: England after the Glorious Revolution. The Journal of Economic History 71 (1), pp. 133-61.

Dahlström, B. (1942). Rikets gäld 1788-1792. Studier i den svenska riksförvaltningen jämte krigsfinansieringen 1788-1790. Stockholm.

Dincecco, M. (2009a). Political Regimes and Sovereign Credit Risk in Europe, 1750-1913. European Review of Economic History 13 (1), pp. 31-63.

Dincecco, M. (2009b). Fiscal Centralization, Limited Government, and Public Revenues in Europe, 1650-1913. The Journal of Economic History 69 (1), pp. 48-103.

Dincecco, M. (2010). The Political Economy of Fiscal Prudence in Historical Perspective. Economics \& Politics 22 (1), pp. 1-36.

Engdahl, T. and Ögren, A. (2008). Multiple Paper Monies in Sweden 1789-1903: Substitution or Complementarity?. Financial History Review 15 (1), pp. 73-91.

Feldbæk, O. (1983). Eighteenth-Century Danish Neutrality: Its Diplomacy, Economics and Law. Scandinavian Journal of History 8 (1), pp. 3-21.

Feldbæk, O. (1993). Danmarks фkonomiske historie 1500-1840. Herning: Systime.

Gärdebo, J. (2009). Staten med rätt att skuldsättas. En studie om statsskulder i Sverige 17891792. In M. Edling and P. Winton (eds), Ett nödvändigt ont. Statsskuld och politik i Förenta Staterna och Sverige 1780-1870. Uppsala: Opuscula Historica Upsaliensia. Glete, J. (2002). War and the State in Early Modern Europe. Spain, the Dutch Republic and Sweden as Fiscal-Military States, 1500-1660. Abingdon: Routledge.

Hallendorff, C. (1920). Bankens öden från mössväldet till den andra realisationen. In Sveriges Riksbank 1668-1918. Bankens tillkomst och verksamhet, vol. III. Stockholm: Norstedt. 
Hårdstedt, M. (2002). Om krigets förutsättningar. Den militära underhållsproblematiken och det civila samhället i norra Sverige och Finland under Finska kriget 1808-09. Umeå: Institutionen för historiska studier.

Hemström, M. (2005). Marschen mot makten. Västra arméns revolt och väg till Stockholm 1809. Uppsala: Acta Universitatis Upsaliensis.

Hoffman, P.T. and Rosenthal, J.-L. (1997). The Political Economy of Warfare and Taxation in Early Modern Europe: Historical Lessons for Economic Development. In J.N. Drobak and J.V.C. Nye (eds), The Frontiers of the New Institutional Economics. San Diego, CA: Academic Press.

Hoffman, P.T. and Rosenthal, J.-L. (2000). Divided We Fall: The Political Economy of Warfare and Taxation. Mimeo, California Institute of Technology.

Johansen, H.C. (1968). Dansk фkonomisk politik i årene efter 1784. Reformår 1784-88. Aarhus: Universitetsforlaget i Aarhus.

Landberg, G. (1932). Den svenska riksdagen under den gustavianska tiden. In Sveriges Riksdag, vol. I:7. Stockholm: Sveriges Riksdag.

Lobell, H. (2010). Foreign Exchange Rates 1804-1914. In R. Edvinsson, T. Jacobson and D. Waldenström (eds) Exchange rates, prices, and wages, 1277-2008. Stockholm: Ekerlid and Sveriges riksbank.

Müller, L. (2011). Sweden's neutral trade under Gustav III: The ideal of commercial independence under the predicament of political isolation. In K. Stapelbroek (ed.), Trade and War: The Neutrality of Commerce in the Inter-State System. Helsinki: Collegium. Studies across Disciplines in the Humanities and Social Sciences, vol. 10. 
North, D.C. and Weingast, B. (1989). Constitutions and Commitment: The Evolution of Institutions Governing Public Choice in Seventeenth-Century England. The Journal of Economic History 49 (4), pp. 803-32.

Nyberg, K. (2010). The Early Modern Financial System and the Informal Credit Market. In A. Ögren (ed.), The Swedish Financial Revolution. Basingstoke: Palgrave Macmillan. O'Brien, P.K. (1988). The Political Economy of British Taxation, 1660-1815. Economic History Review, $2^{\text {nd }}$ ser. 41 (1), pp. 1-32.

O'Brien, P.K. (2009). The Triumph and Denouement of the British Fiscal State: Taxation for the Wars against Revolutionary and Napoleonic France, 1793-1815. In C. Storrs (ed.), The Fiscal-Military State in Eighteenth-Century Europe. Essays in honour of P.G.M. Dickson. Farnham: Ashgate.

O’Rourke, K.H. (2006). The Worldwide Economic Impact of the French Revolutionary and Napoleonic Wars, 1793-1815. Journal of Global History 1, pp. 123-49.

Pincus, S.C.A. and Robinson, J.A. (2011). What Really Happened During the Glorious Revolution?. NBER Working Papers No. 17206.

Riley, J.C. (1980). International Government Finance and the Amsterdam Capital Market, 17401815. Cambridge: Cambridge University Press.

Rosenthal, J.-L. (1998). The Political Economy of Absolutism Reconsidered. In R.H. Bates et al, Analytic Narratives. Princeton, NJ: Princeton University Press.

Schön, L. (2010). The Rise of the Fiscal State in Sweden, 1800-1914. In J.L. Cardoso and P. Lains (eds), Paying for the Liberal State. The Rise of Public Finance in NineteenthCentury Europe. Cambridge: Cambridge University Press.

Scott, H.M. (2006). The Birth of a Great Power System, 1740-1815. Harlow: Pearson. 
Stasavage, D. (2007). Partisan Politics and Public Debt: The Importance of the 'Whig Supremacy' for Britain’s Financial Revolution. European Review of Economic History 11 (1), pp. 123-53.

Sundin, A. (2006). 1809. Statskuppen och regeringsformens tillkomst som tolkningsprocess. Uppsala: Acta Universitatis Upsaliensis.

Svendsen, K. E. and Hansen, S.A. (1968), Dansk pengehistorie 1700-1914. Copenhagen: Danmarks Nationalbank.

Tandefelt, H. (2008). Konsten att härska. Gustaf III inför sina undersåtar. Helsinki: Svenska litteratursällskapet i Finland.

Thompson, I.A.A. (1994). Castile: Absolutism, Constitutionalism, and Liberty. In P.T. Hoffman and K. Norberg (eds), Fiscal Crises, Liberty, and Representative Government 1450-1789. Stanford CA: Stanford University Press.

Weber, D. (2008). Das Handels- und Bankhaus Frege \& Comp. in Leipzig (1739-1816). Stuttgart: Franz Steiner Verlag.

White, E.N. (1995). The French Revolution and the Politics of Government Finance, 1770-1815. The Journal of Economic History 55 (2), pp. 227-255.

Wilcke, J. (1929). Specie-, kurant- og rigsbankdaler. Mфntvaesenets sammenbrud og genrejsning 1788-1845. Copenhagen.

Winton, P. (2009). Den högsta maktens verkningskraft. Statsskuld och politik i Sverige 18001815. In M. Edling and P. Winton (eds), Ett nödvändigt ont. Statsskuld och politik $i$ Förenta Staterna och Sverige 1780-1870. Uppsala: Opuscula Historica Upsaliensia.

Zanden, J.L. van and Riel, A. van (2004). The Strictures of Inheritance: The Dutch Economy in the Nineteenth Century. Princeton: Princeton University Press. 